\title{
Assessment of some Physical and Chemical Properties of Soils in West Edfu Area, Aswan Governorate, Egypt \\ Abdalazem, A.H. ${ }^{1}$; H.M. Khozyem ${ }^{2}$; M.A. Gamee ${ }^{3}$; A.A.M. Awad ${ }^{1}$ and A.G. Mohamed $^{1}$ \\ ${ }^{1}$ Faculty of Agriculture and Natural resources, Aswan University. \\ ${ }^{2}$ Geology Department, Faculty of Science, Aswan University. \\ ${ }^{3}$ Faculty of Agriculture, Assiut University.
}

Received on: 6/2/2020

Accepted for publication on: 11/3/2020

\section{Abstract}

The soils in west Edfu are promising for land reclamation projects due to their location nearby the urban areas and availability of groundwater resources for crop irrigation. The objectives of this work were to evaluate of some physical and chemical properties of west Edfu soils which are located in the western part of the Aswan Governorate. The obtained results indicated that the majority of soils in the area under study is sandy textured, which had a very significant impact on their physical and chemical properties. The values of saturation percentage (SP) and soil porosity (E) are low, whereas the values of bulk density $\left(\rho_{\mathrm{b}}\right)$ were high especially in the western part of the study area. Electrical conductivity (ECe) values of the saturated soil past extracts in general vary between 1.29 to $61.29 \mathrm{dsm}^{-1}$ with an average of $11.94 \mathrm{dS} / \mathrm{m}$. The $\mathrm{pH}$ values of all studied soils are generally above 7.00 with a range of 7.12 to 8.95 and an average value of 7.76. On the other hand, the cations exchange capacity (CEC) values were low in most of the studied soils and it is ranges from 1.38 to $45.84 \mathrm{cmol}^{(+)} / \mathrm{kg}$ with a mean value of $11.15 \mathrm{cmol}^{(+)} / \mathrm{kg}$. In the area under study the ESP values vary between 0.59 to $40.55 \%$ with an average value of $16.39 \%, \mathrm{CaCO}_{3}$ in the studied soils ranges from 0.43 to $41.74 \%$ with a mean value of $7.23 \%$. Gypsum content varies from 0.09 to $11.53 \%$ with an average value of $3.08 \%$. In general, the dominance of salt composition in soils is $\mathrm{Na}_{2} \mathrm{CO}_{3}$ and $\mathrm{CaCO}_{3}$ and sometimes $\mathrm{MgCO}_{3}$ in sodic soils. The cationic composition of the soil is dominated by $\mathrm{Na}^{+}$followed by $\mathrm{Ca}^{+2}$ and then $\mathrm{Mg}^{+2}$ and $\mathrm{K}^{+}$. Exceptional cases were found in some soil samples $\mathrm{Ca}^{+2}$ exceed $\mathrm{Na}^{+}$. The anionic composition is characterized by the dominance of $\mathrm{Cl}^{-}$followed by $\mathrm{HCO}_{3}{ }^{-}$then $\mathrm{SO}_{4}{ }^{-2}$ while $\mathrm{CO}_{3}{ }^{-2}$ in entirely absent. The results also indicate that the soluble cations and anions are very wide in range and distribution among the different locations.

Keywords: West Edfu, physical properties, chemical properties, spatial variability.

\section{Introduction}

The socio-economic development plan of Egypt (plan 2030) is principally based on land and water resources. Recently, the Egyptian government is interested in developing desert fringes area located in the western desert and situated between the Nile valley and the limestone plateau. In this strategy, more than 1.5 million feddans in the western desert will subjected to sustainable development strategy that mainly depends on land reclamation (El-Baz, 2007). West Edfu area is a part of El-Galaba basin and which considers one of 
twelve sectors that will be included in this project. The climatic conditions of the study area are typically arid to semi-arid, characterized by a long hot dry summer, mild winter to high relative humidity. Although rainfall is not significant throughout the year, some rare and irregular storms take place over scattered localities during the winter season. Currently, information about the variability within soil properties is considered as one of the major fundamentals for local management in precision farming. Therefore, studying the spatial variability of both soil physical and chemical properties is very relevant for understanding the soil processes and for land management. Spatial variability of soil properties either over the horizontal or vertical directions generally result from the interaction between the soil forming factors; however some of them are due to management practices (Papadopoulos et al., 2006; and Muhaimeed and Saleh, 2013). Soil is a component of the terrestrial ecosystem that performs many functions including those that are essential for sustaining plant growth (Paudel and Sah, 2003). Physic-chemical characteristics of different soils vary in space and time due to variation in topography, climate, physical weathering processes, vegetation cover, microbial activities and several other biotic and abiotic variables (Nwachokor, et al., 2009). A soil that supplies adequate nutrients needed by plants with favorable soil $\mathrm{pH}$ will produce better crops quality and yield if other conditions of growth such as biological and physical properties of the soil are favorable (Olueh, 2014). (Ghafari et al., 2000), reported that geographic information system (GIS) plays a major role in spatial decisionmaking. The collected information for the suitability analysis for crop production should present both opportunities and constraints for the decision maker remote sensing and GIS were used in many studies in Egypt for land resources mapping and management (Saleh et al., 2013; Saleh and Belal, 2014). The objectives of this work were to study soil physiochemical properties and their spatial distribution in west Edfu using GIS.

\section{Geology, Topography and Geo- morphology Setting}

The morphological features of the area under study as a part of the west Nile valley are divided by (Farrag, 1982) into the following surface unite: These are 1). The young alluvial plain of the Nile which is traversed by the River Nile. 2) The old alluvial plains of the Nile which comprise the terraces found at various heights on both the eastern and western sides of the Nile Valley. They were formed as a result of the aggradation and degradation of the Nile Valley relative to the change in the Mediterranean Sea level. 3) The calcareous structural plateau and its bounding slopes. The plateau is underlain by Eocene lime stones. It lies on both sides of the Nile Valley with cliffs overlooking the flood plain at the northern part of the area. 4) The structural plains which occupy the southern portion of the area. They are essentially underlain by the Nubian Sandstone, and 5). The desert hydrographic basins which include the dry drainage lines directed into the Nile Basin and traversing the structural plains and the calcareous plateau. 
The topography of the investigated area is generally irregular. A number of small, shallow and dry wadies run towards the Nile and are mainly controlled by the ENE-WSW and E-W Fractures and by rock texture (El-Shazly et al., 1975). Also several isolated hills are present.

Geologically, the Nubia formation of Cretaceous age (Issawi, 1981) which covers all the examined area and overlies the basement rocks, is mainly composed of sand and sandstone with clay and shale intercalations of irregular thicknesses (Fig.1). The structure of the area, which represents a part of West Aswan area, is dominated by ENE-WSW trending open folds of regional and local scale, while the fractures and faults have several trends and partly extend across long distances, some are short and grouped together in parallel arrangement accompanying the major fractures (El-Shazly et al., 1975).

\section{Material and Methods}

\subsection{Digital data and image} processing: The following remote sensing analyses used data from Landsat Data Continuity Mission (LDCM) sensor (Landsat 8) covering the study area acquired under clear sky conditions dated to the year 2018 .

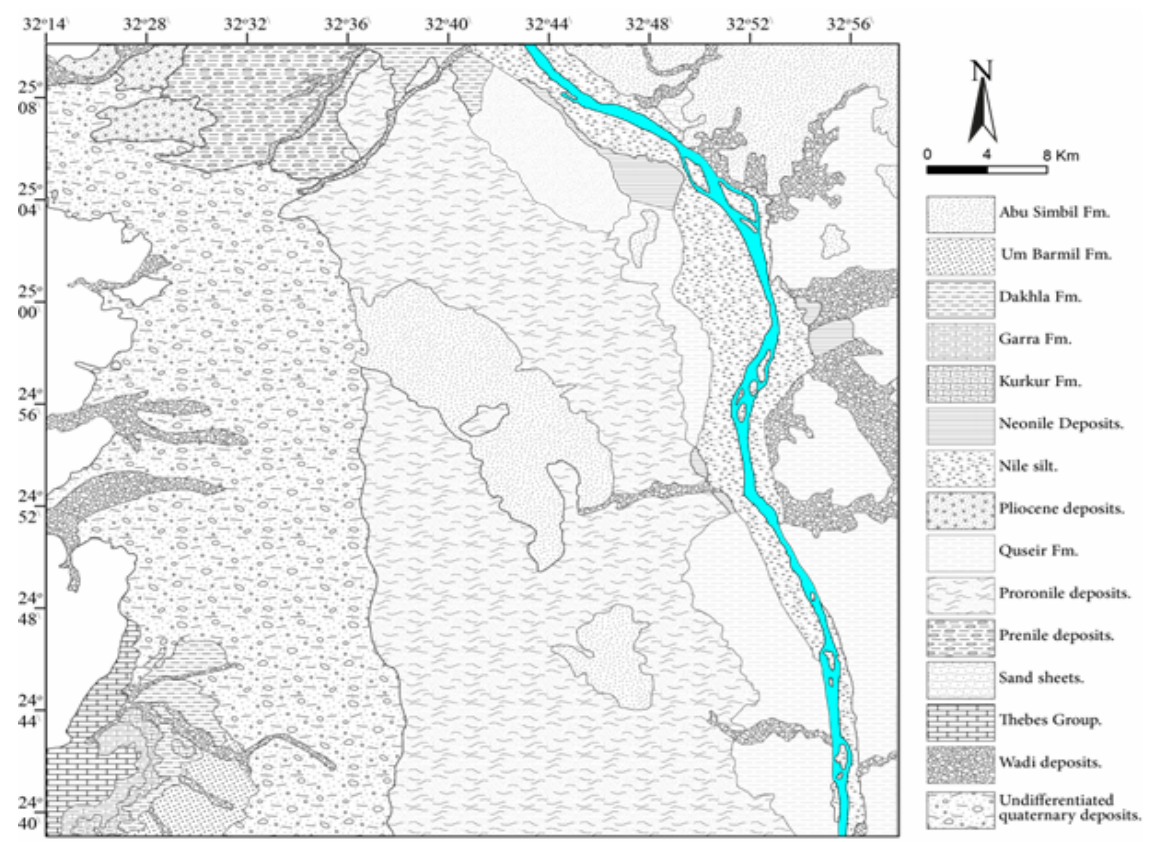

Figure 1: Geological map of the west Edfu area. 


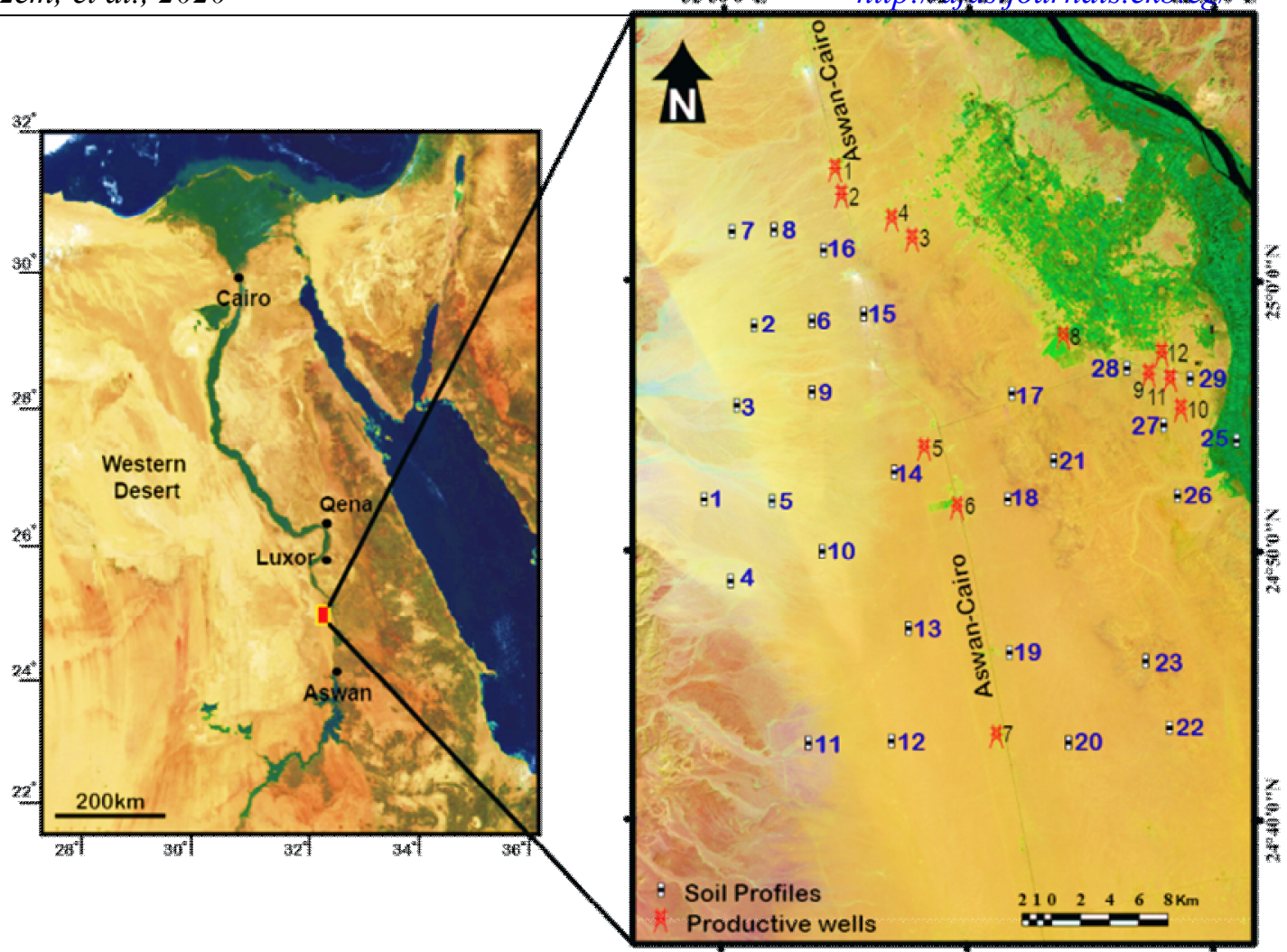

Figure 2: Sample location map of the studied soil in the desert fringes area west of Edfu.

Data of the blue to the shortwave infrared portion of the spectrum were used in this study. At first, the Thermal Infra-Red Sensor (TIRS) bands, the coastal and the cirrus bands were excluded due to the nature of the study. The $30-\mathrm{m}$ spatial resolutions of operational Land Imager (OLI) data were resampled to the higher $15-\mathrm{m}$ resolution of the panchromatic band. All further digital image processing and analyses were executed using the standard approaches provided by the software ENVI 5.0. Stretching, contrast enhancement and an enhanced false color com- posite of bands (7, 4 and 1) (Fig. 2) of land sat image were applied and visually interpreted on the screen after overlaying Main Characteristics of the Identified Physiographic Units:

To achieve the goals of the present study, the geopedological map "soil map" of the studied region was produced firstly throughout the integration for physiographic interpretation of satellite image, which overlaid on a digital elevation model (DEM) using GIS. The geopedological map of the studied area is illustrated in (Fig. 3). 


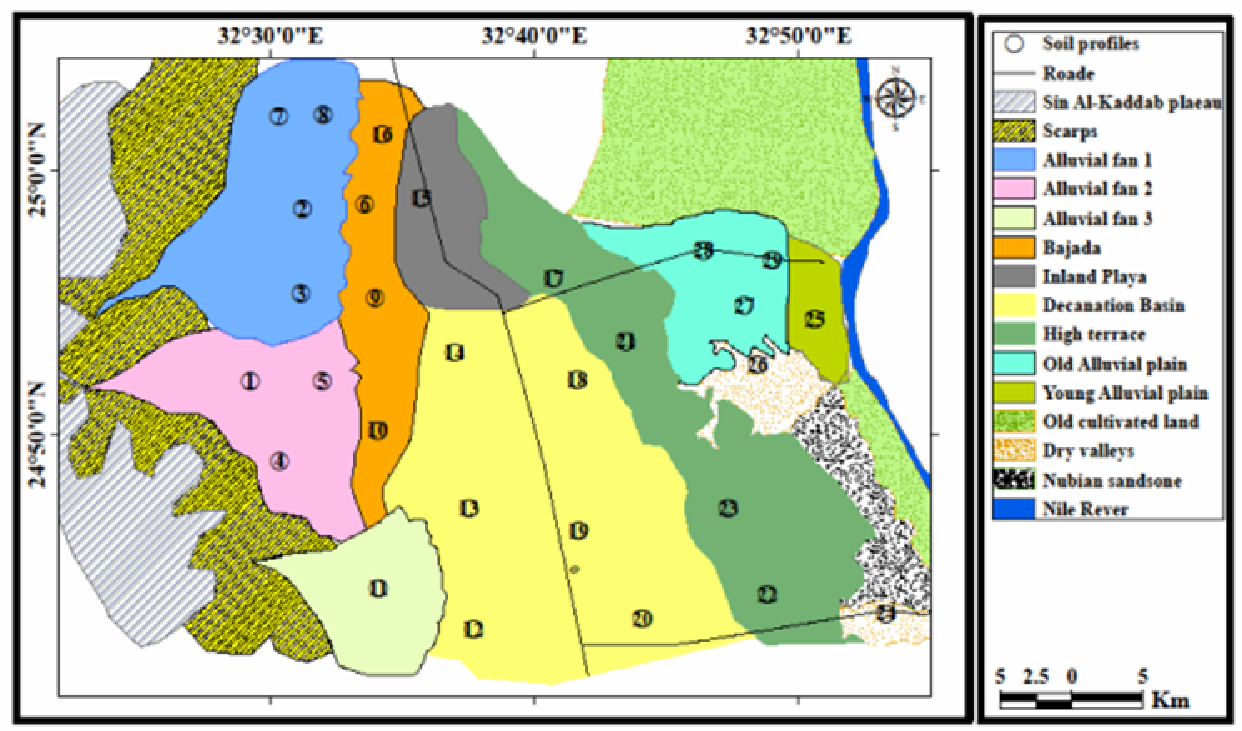

Figure 3: The geopedological map of the area under study.

The visual interpretation of satellite images for the studied area demonstrated fourteen map units, i.e., Sin al-kaddab plateau, scarps, alluvial fan1, alluvial fan 2, alluvial fan 3, bajada, decantation basin, inland playa, high terrace, old alluvial plain, young alluvial plain, dry valleys, Nubian sandstone and old cultivated land. The different map unit in the study area and its distribution were represented in Table 1.

Table 1. The geopedological map legend of the studied area.

\begin{tabular}{|c|c|c|c|c|}
\hline SMU & Map Units & Area (Feddan) & Area $\left.\mathbf{( K m}^{\mathbf{2}}\right)$ & $\mathbf{( \% )}$ \\
\hline $\mathbf{1}$ & Sin Al-Kaddab Plateau & 61166 & 257 & 11.90 \\
\hline $\mathbf{2}$ & Scarps & 62356 & 262 & 12.13 \\
\hline $\mathbf{3}$ & Alluvial fan 1 & 40698 & 171 & 7.92 \\
\hline $\mathbf{4}$ & Alluvial fan 2 & 31178 & 131 & 6.06 \\
\hline $\mathbf{5}$ & Alluvial fan 3 & 19278 & 81 & 3.75 \\
\hline $\mathbf{6}$ & Bajada & 27846 & 117 & 5.42 \\
\hline $\mathbf{7}$ & Decantation Basin & 84728 & 356 & 16.48 \\
\hline $\mathbf{8}$ & Inland playa & 16898 & 71 & 3.29 \\
\hline $\mathbf{9}$ & High terrace & 60214 & 253 & 11.71 \\
\hline $\mathbf{1 0}$ & Old alluvial plain & 21420 & 90 & 4.17 \\
\hline $\mathbf{1 1}$ & Young alluvial plain & 5950 & 25 & 1.16 \\
\hline $\mathbf{1 2}$ & Dry valleys & 9758 & 41 & 1.90 \\
\hline $\mathbf{1 3}$ & Nubian sand stone & 15232 & 64 & 2.96 \\
\hline $\mathbf{1 4}$ & Old cultivated land & 57358 & 241 & 11.16 \\
\hline Total & & 514080 & 2160 & 100 \\
\hline
\end{tabular}

\section{General Description of the Study} Area

West Edfu is a part of ElGallaba plain in the western desert. It is located about $120 \mathrm{~km}$ north of Aswan Governorate. El-Gallaba plain is the largest and greatest dry valley which runs in western desert for a 
distance of about $150 \mathrm{Km}$. However, with width varies from 45-60 Km. The study area extends between lati-

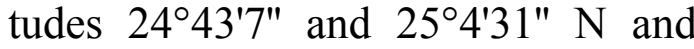
longitudes $32^{\circ} 27^{\prime} 58^{\prime \prime}$ and $32^{\circ} 50^{\prime} 21^{\prime \prime}$ E. The study area in El-Gallaba plain is a desert area with no natural vegetation (Fig. 2).

\section{Field and laboratory work}

\subsection{Soil samples}

The field work was done in February, 2018. A general reconnaissance survey was firstly carried out by using intensive auger testing. Transect sampling method is applied through the different mapping units in the study area. Twenty nine soil profiles were collected (Fig. 2). Each profile was dug to $1.5 \mathrm{~m}$ depth. All profiles were prepared and described and classified according to the stan- dard scheme and terminology of FAO (2006) and American Soil Survey Staff (2014). The exact locations were recorded using GPS.

Eighty-one soil samples were collected from the 29 soil profile covering the different soil layers. The samples were taken from each notable vertical variation in the morphology of vertical profile. The collected soil samples were subjected to physical and chemical analysis to determine the different soil properties.

\subsection{Soil Physical properties}

For the physical soil parameter, bulk soil samples were air-dried; crushed, and sieved through $2 \mathrm{~mm}$ screen. The studied physical soil parameter includes soil texture, color, bulk density, particle density and porosity.

Table 2. Physical methods of soil samples.

\begin{tabular}{|c|l|l|}
\hline Properties & \multicolumn{1}{|c|}{ Method applied } & \multicolumn{1}{c|}{ Reference } \\
\hline $\begin{array}{c}\text { The particle size dis- } \\
\text { tribution }\end{array}$ & $\begin{array}{l}\text { Using the international pipette } \\
\text { method using sodium hexameta } \\
\text { phosphate as a dispersing agent. }\end{array}$ & $\begin{array}{l}\text { Piper, (1950) } \\
\text { Richards, (1954) }\end{array}$ \\
\hline Soil color & $\begin{array}{l}\text { dry and moist samples were deter- } \\
\text { mined according Munsell color } \\
\text { charts }\end{array}$ & Soil survey staff, (1951) \\
\hline The bulk density & graduated cylinder method & Bodman, (1946) \\
\hline The particle density & using the pycnometer method & Blake and Hartge, (1986). \\
\hline The total porosity & $\begin{array}{l}\text { Porosity \% }=\{1-(B u l k \text { den- } \\
\text { sity/particle density) }\} \times 100\end{array}$ & $\begin{array}{l}\text { Danielson and Sutherland } \\
(1986)\end{array}$ \\
\hline
\end{tabular}

\subsection{Chemical analysis}

- Soil chemical properties including $\mathrm{pH}, \mathrm{CaCO}_{3}, \mathrm{ECe}$, soluble cations and anions, CEC and ESP were measured as described by Jackson 1973.

- The gypsum was determined in the soil samples using acetone method according to Nelson, (1982).

\section{Results and Discussions}

\subsection{Physical properties of soil map units}

Fourteen mapping units were extracted, identified and grouped in west Edfu area. Ten mapping units were identified as soil mapping units (SMU) while the other four mapping units were identified as rocky nonsoil mapping units (RMU). The soil 
mapping units (SMU) of the area under study and their associated soils were identified and delineated as shown in (Fig. 3). These mapping units (SMU) were grouped based on the soil layers similar in differentiating characteristics and arrangement in the soil profiles and developed from a particular type of parent material. The soils within the soil units are essentially homogeneous in all soil characteristics. Representative physical properties of soils in the study area are shown in Table 3. The following is a brief description of the area under study.

Generally, a texture grad of the area under study is mostly coarse (mainly sand, loamy sand and sandy loam). The sandy texture dominates in most soil profiles, especially in the western part of the study area which it represents about $58.02 \%$ of the soil material, followed by the loamy sand texture it occurs in the middle part of the area under investigated (it covers about $25.93 \%$ of the total area), then the sandy loam prevails in the eastern part of the studied soil profiles it is about $16.05 \%$ of the total area. In most cases, a soil texture becomes finer with depth, especially in the eastern part of the study area (Table 3 and Fig. 4-A). Most of soil samples in the study area have gravels content less than $15 \%$ it is about $54.32 \%$ of the total samples. While, the gravelly soil (gravel content ranging between 15 to $35 \%$ ) represents about $32.1 \%$ of the total samples. Very gravelly soil (gravels content more than $35 \%$ ) is about $13.58 \%$ of the total soil samples. In addition to average values of gravel content are $17.13 \%$ and the general profiles weighted mean ranged between 2.65 to $40.63 \%$ (Table 3 ). 
Table 3. Soil physical properties for weighted profiles mean of soil map units (SMUs) in the study area.

\begin{tabular}{|c|c|c|c|c|c|c|c|c|c|c|c|}
\hline \multirow{2}{*}{ Mapping Unit } & \multirow{2}{*}{$\begin{array}{c}\text { Profile } \\
\text { No. }\end{array}$} & \multirow{2}{*}{$\begin{array}{c}\text { Depth } \\
\text { of } \\
\text { profiles } \\
\text { (cm) }\end{array}$} & \multirow{2}{*}{$\begin{array}{c}\text { Gravel } \\
(\%)\end{array}$} & \multicolumn{3}{|c|}{$\begin{array}{c}\text { Particle size } \\
\text { distribution (\%) }\end{array}$} & \multirow{2}{*}{$\begin{array}{c}\text { Textural } \\
\text { grade }\end{array}$} & \multirow{2}{*}{\begin{tabular}{|c} 
Saturation \\
Percentage \\
capacity \\
$(\%)$
\end{tabular}} & \multirow{2}{*}{$\begin{array}{r}\text { Particle } \\
\text { Density } \\
\left(\mathbf{M g} / \mathrm{m}^{3}\right)\end{array}$} & \multirow{2}{*}{$\begin{array}{c}\text { Bulk density } \\
\left(\mathrm{Mg} / \mathrm{m}^{3}\right)\end{array}$} & \multirow{2}{*}{\begin{tabular}{|c|} 
Total \\
Porosity \\
$(\%)$
\end{tabular}} \\
\hline & & & & Sand & Silt & Clay & & & & & \\
\hline \multirow{4}{*}{ Alluvial Fan1 } & 2 & 150 & 10.91 & 92.56 & 7.04 & 0.40 & Sand & 19.43 & 2.54 & 1.68 & 33.98 \\
\hline & 3 & 150 & 7.73 & 96.56 & 2.83 & 0.61 & Sand & 18.04 & 2.57 & 1.68 & 34.84 \\
\hline & 7 & 150 & 4.12 & 92.35 & 6.95 & 0.70 & Sand & 20.23 & 2.61 & 1.73 & 33.80 \\
\hline & 8 & 150 & 11.68 & 93.17 & 4.84 & 1.99 & Sand & 21.72 & 2.61 & 1.67 & 35.85 \\
\hline \multirow{3}{*}{ Alluvial Fan2 } & 1 & 150 & 11.64 & 94.00 & 3.20 & 2.80 & Sand & 20.00 & 2.59 & 1.69 & 34.70 \\
\hline & 4 & 150 & 15.22 & 91.07 & 7.44 & 1.49 & Sand & 21.27 & 2.59 & 1.66 & 36.00 \\
\hline & 5 & 150 & 15.60 & 93.52 & 3.84 & 2.64 & Sand & 20.35 & 2.58 & 1.61 & 37.55 \\
\hline Alluvial Fan3 & 11 & 150 & 14.22 & 91.19 & 8.04 & 0.77 & Sand & 20.31 & 2.59 & 1.70 & 34.40 \\
\hline \multirow{4}{*}{ Bajada } & 6 & 150 & 8.88 & 93.33 & 5.93 & 0.73 & Sand & 20.00 & 2.64 & 1.78 & 32.46 \\
\hline & 9 & 150 & 12.92 & 93.87 & 3.93 & 2.20 & Sand & 20.44 & 2.62 & 1.75 & 33.14 \\
\hline & 10 & 150 & 21.14 & 91.63 & 6.32 & 2.05 & Sand & 20.36 & 2.62 & 1.72 & 34.42 \\
\hline & 16 & 150 & 18.90 & 87.48 & 11.64 & 0.88 & Sand & 29.26 & 2.61 & 1.76 & 32.81 \\
\hline Inland playa & 15 & 150 & 16.28 & 81.52 & 14.69 & 3.79 & Loamy sand & 29.21 & 2.53 & 1.60 & 36.85 \\
\hline \multirow{6}{*}{ Decantation Basin } & 12 & 150 & 16.13 & 81.44 & 11.03 & 7.57 & Loamy sand & 24.10 & 2.56 & 1.77 & 30.65 \\
\hline & 13 & 150 & 7.82 & 85.85 & 8.53 & 5.61 & Loamy sand & 22.32 & 2.59 & 1.75 & 32.32 \\
\hline & 14 & 150 & 17.21 & 88.45 & 9.01 & 2.53 & Sand & 21.50 & 2.55 & 1.69 & 33.45 \\
\hline & 18 & 150 & 31.27 & 80.79 & 12.01 & 7.20 & Loamy sand & 27.74 & 2.61 & 1.75 & 32.90 \\
\hline & 19 & 150 & 40.63 & 89.55 & 8.55 & 1.91 & Sand & 18.77 & 2.68 & 1.76 & 34.35 \\
\hline & 20 & 150 & 22.11 & 75.20 & 16.48 & 8.32 & Sandy loam & 29.88 & 2.66 & 1.81 & 32.06 \\
\hline \multirow{4}{*}{ High terrace } & 17 & 150 & 14.06 & 66.48 & 20.64 & 12.67 & Sandy loam & 33.35 & 2.59 & 1.65 & 36.27 \\
\hline & 21 & 150 & 39.62 & 82.97 & 11.41 & 5.63 & Loamy sand & 26.94 & 2.63 & 1.81 & 31.27 \\
\hline & 22 & 150 & 14.24 & 64.72 & 20.64 & 14.64 & Sandy loam & 29.33 & 2.68 & 1.76 & 34.30 \\
\hline & 23 & 150 & 29.61 & 82.64 & 9.33 & 8.03 & Loamy sand & 24.48 & 2.71 & 1.54 & 43.10 \\
\hline \multirow{3}{*}{ Old alluvial plain } & 27 & 150 & 2.95 & 82.48 & 15.39 & 2.13 & Loamy sand & 29.32 & 2.65 & 1.71 & 35.47 \\
\hline & 28 & 150 & 13.08 & 72.56 & 17.71 & 9.63 & Sandy loam & 35.65 & 2.62 & 1.50 & 42.99 \\
\hline & 29 & 150 & 36.42 & 87.84 & 10.76 & 1.40 & Sand & 21.04 & 2.65 & 1.80 & 31.98 \\
\hline Young alluvial plain & 25 & 150 & 5.66 & 67.97 & 20.24 & 11.83 & Sandy loam & 34.33 & 2.61 & 1.65 & 36.82 \\
\hline \multirow{2}{*}{ Dry valleys } & 24 & 150 & 20.50 & 91.39 & 7.07 & 1.55 & Sand & 19.80 & 2.73 & 1.78 & 34.73 \\
\hline & 26 & 150 & \begin{tabular}{|l|}
13.83 \\
\end{tabular} & 95.21 & 4.31 & 0.48 & Sand & 16.63 & 2.72 & 1.81 & 33.58 \\
\hline
\end{tabular}



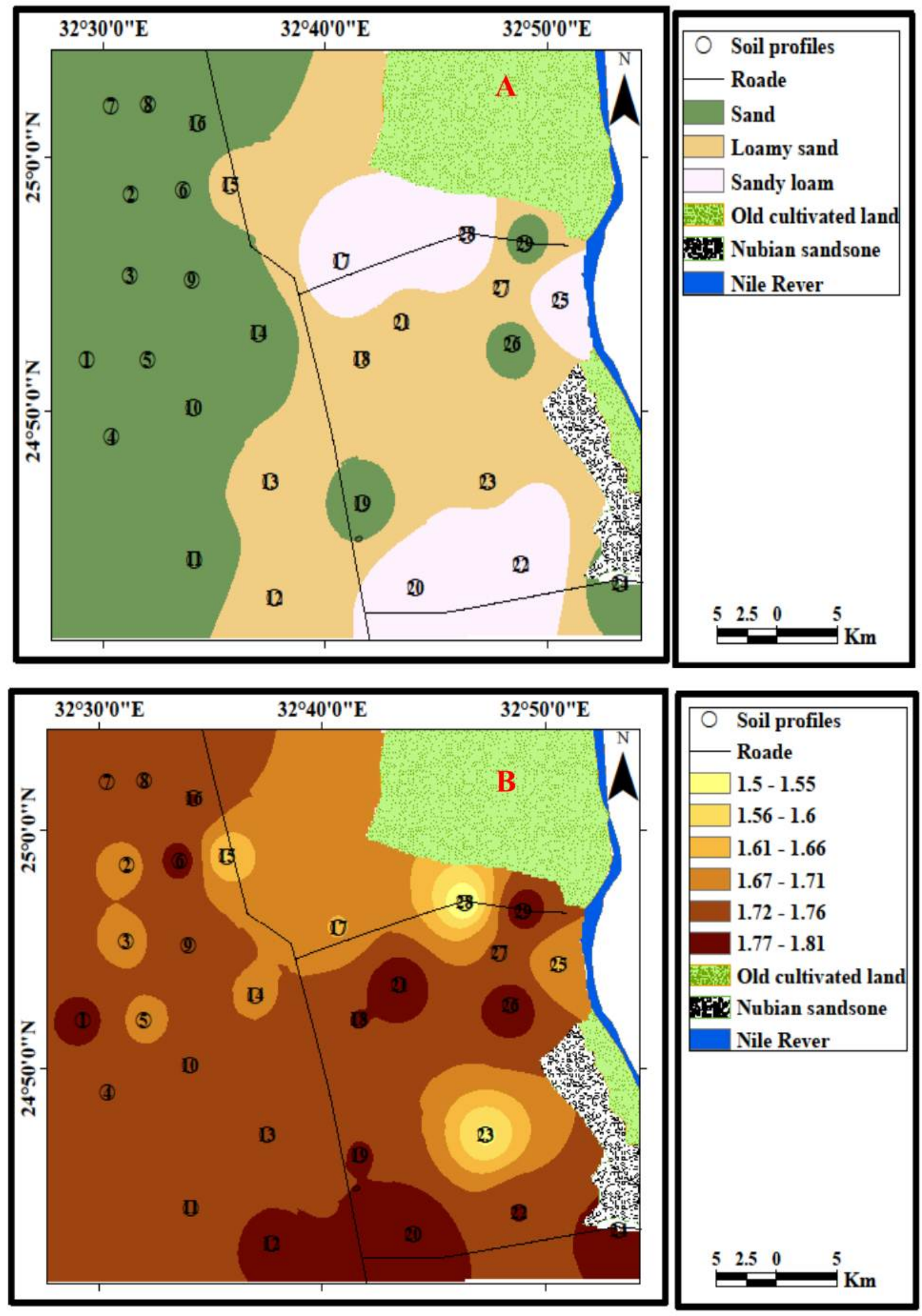

Fig.4. Spatial distribution of A) soil texture and B) bulk density $\left(\mathrm{Mg} / \mathrm{m}^{3}\right)$ of weighted profiles mean in the study area. 
The saturation percentage of most soil samples in the studied area have lower values, especially in the western part of the study area (it has ranged from 16 to $41.87 \%$ with an average of $23.36 \%$ while, the weighted profile mean ranged between 16.63 to $35.65 \%$ Table 3 . The bulk density values in the area under study range from 1.40 to $1.85 \mathrm{Mg} / \mathrm{m}^{3}$ and also weighed profiles mean are differs from 1.50 to $1.81 \mathrm{Mg} / \mathrm{m}^{3}$ (Table 3 and Fig. 4-B). About $96.29 \%$ of the total area has high to very high bulk density values that ranges from 1.45 to $1.85 \mathrm{Mg} / \mathrm{m}^{3}$, while the soils that having moderate bulk density values $\left(1.20\right.$ to $\left.1.45 \mathrm{Mg} / \mathrm{m}^{3}\right)$ represent only $3.70 \%$ of the total area. The distribution pattern of the total porosity values differs from 27.45 to $46.41 \%$ with an average value of $34.68 \%$ while, the weighted profiles mean vary from 30.65 to $43.10 \%$ (Table 3 and Fig. 5-A). On other hand, the particle density in these soils ranged between 2.50 to $2.78 \mathrm{Mg} / \mathrm{m}^{3}$ with a mean value of $2.62 \mathrm{Mg} / \mathrm{m}^{3}$ while the weighted profiles mean are vary from 2.53 to $2.73 \mathrm{Mg} / \mathrm{m}^{3}$ (Table 3 and Fig. 5-B).

\subsection{Chemical soil properties of map units}

In general, like most of the Egyptian soils, the studied soil $\mathrm{pH}$ values great than 7.0 with a range of 7.12 to 8.95 and an average value of
7.76 while, the profiles weighted mean vary from 7.30 to 8.39 (Data in Table 4 and Fig. 6-A). According to the alkaline classification Cook, 1967, about $79.01 \%$ of total soil samples have $\mathrm{pH}$ values are moderately alkaline, $18.52 \%$ are slightly alkaline and $2.47 \%$ are strongly alkaline. ECe in the study area ranges from 1.29 to $61.29 \mathrm{dS} / \mathrm{m}$ with an average of $11.94 \mathrm{dS} / \mathrm{m}$ while the weighted profiles mean ranges from 1.64 to $42.83 \mathrm{dS} / \mathrm{m}$ (Data in Table 4 and Fig. 6-B), indicating salt free saline to very strongly saline according to Sys and Verheye, 1978. Data in Table 4 and show in Figure 7-A) indicated that the weighted mean value of $\mathrm{CaCO}_{3}$ content range between 0.94 to $32.17 \%$ while, values of $\mathrm{CaCO}_{3}$ in the all soil samples ranges from 0.43 to $41.74 \%$ with a mean value of $7.23 \%$. In other words, according to FAO, 2006 about 19.75\% of soil samples in the study area is slightly calcareous, $59.26 \%$ are moderately calcareous, $18.52 \%$ are strongly calcareous and $2.47 \%$ are extremely calcareous soils.

Soil gypsum content in the area under investigation varies from 0.09 to $11.53 \%$ with an average value of $3.08 \%$ while, the weighted mean value of gypsum content vary from 0.16 to $7.90 \%$ is given in (Table 4 and showed in Figure 7-B). 

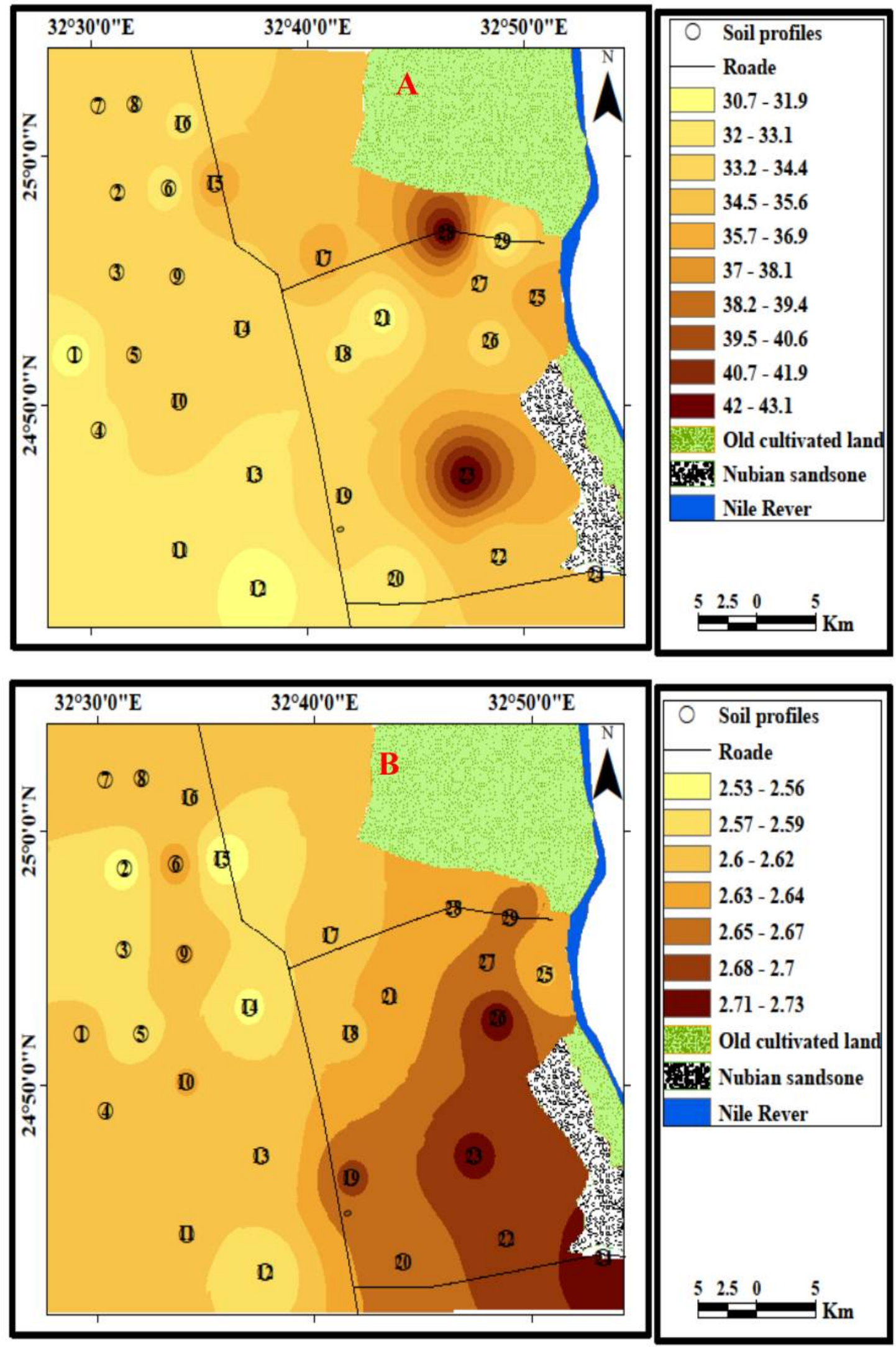

Fig.5. Spatial distribution of A) total porosity (\%) and B) Particle density $\left(\mathrm{Mg} / \mathrm{m}^{3}\right)$ of weighted profiles mean in the study area 
Doi: 10.21608/ajas.2020.108427

Abdalazem, et al., 2020

http://ajas.journals.ekb.eg/ 

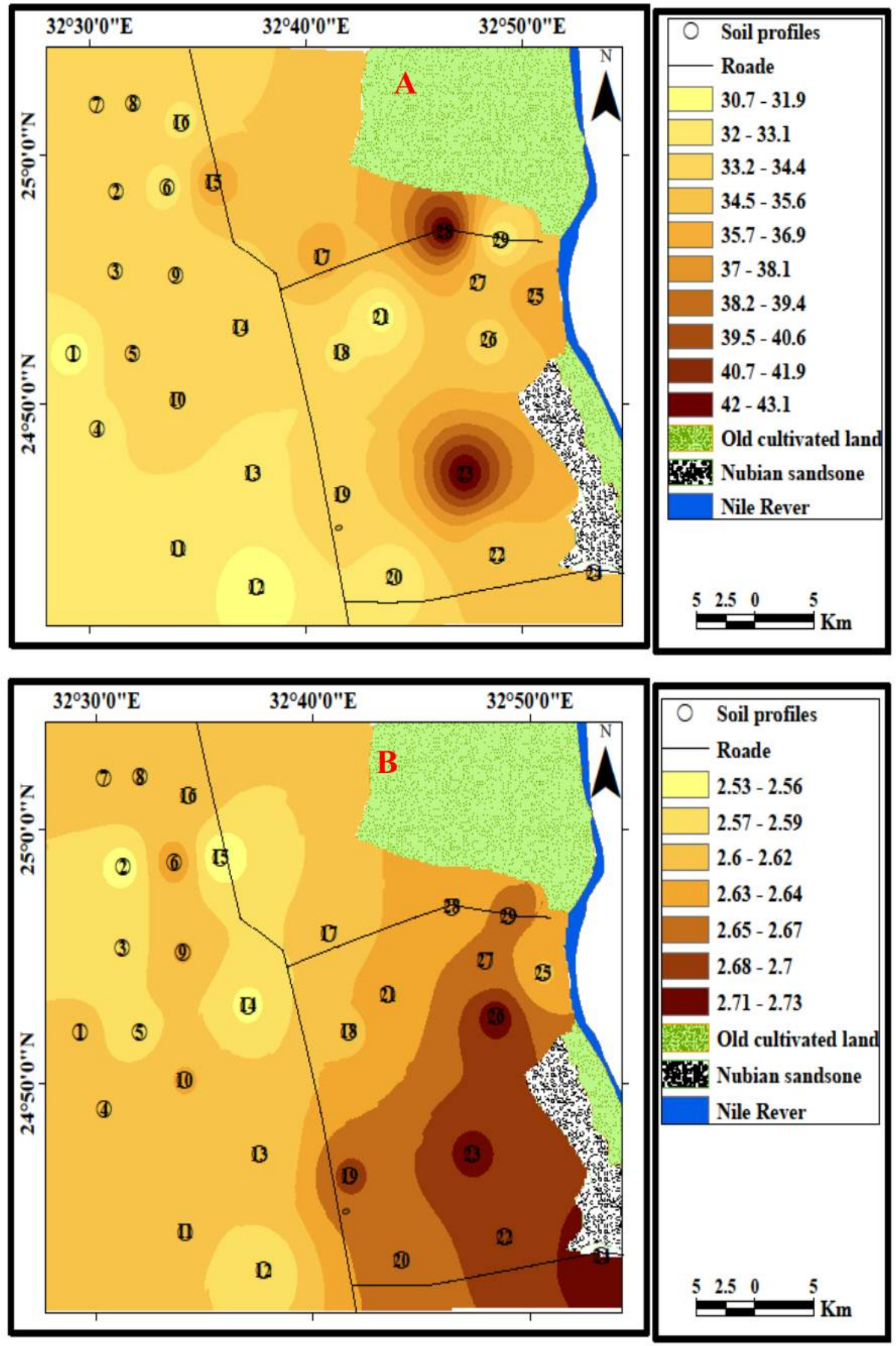

Fig.6. Spatial distribution of A) soil $\mathrm{pH}$ and $\mathrm{B}$ ) ECe of weighted profiles mean in the study area 

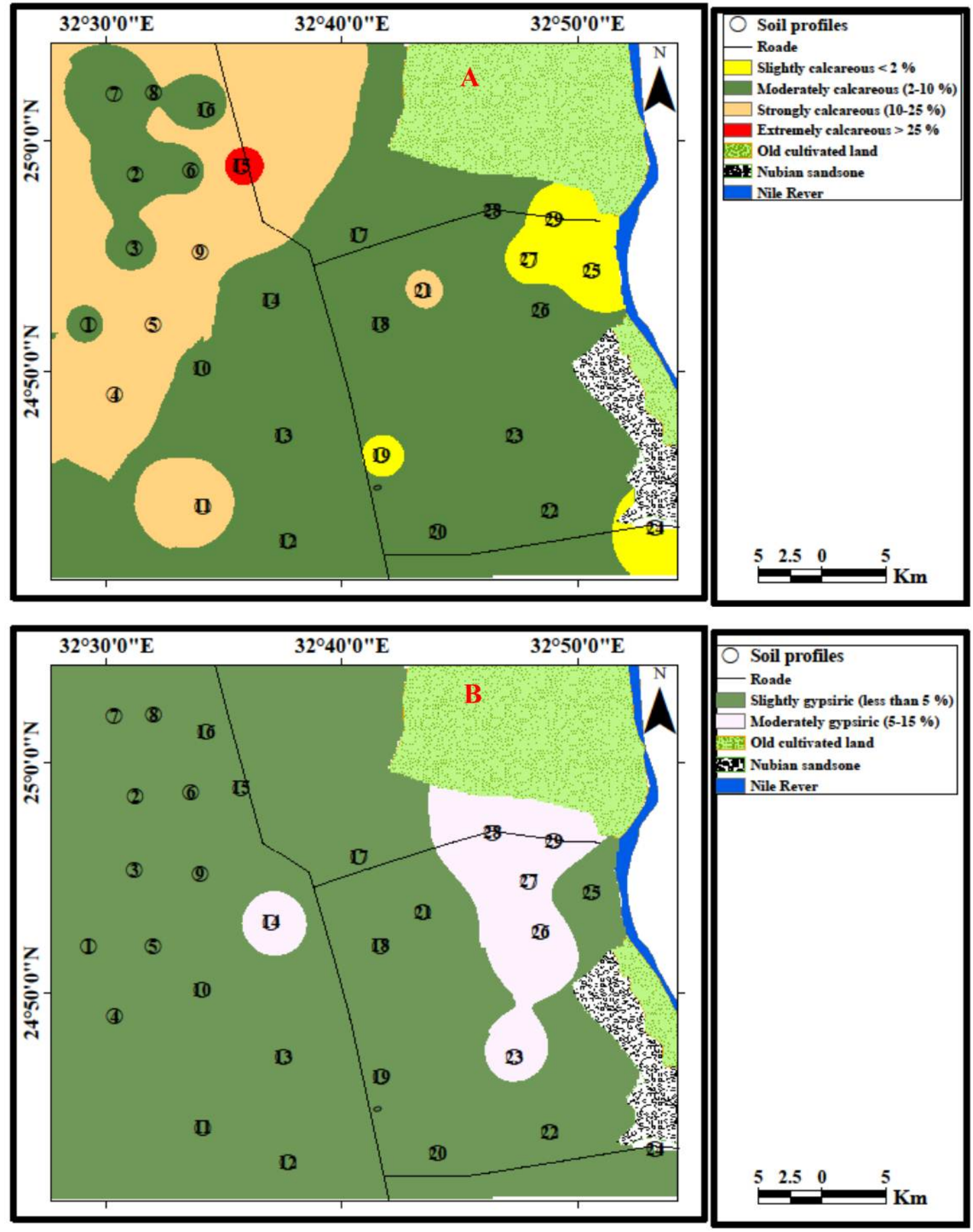

Fig.7: Spatial distribution of $\mathrm{A}) \mathrm{CaCO}_{3}$ content (\%) and $\mathrm{B}$ ) Gypsum content (\%) of weighted profiles mean in the area under study. 
The exchangeable sodium percentage (ESP) in the area under study vary between 0.59 to $40.55 \%$ with an average value of $16.39 \%$, while, the weighted profiles mean of ESP values range from 2.53 to $33.89 \%$ (Fig. 8 A). The highest values of ESP are associated with subsurface and the deepest layers of profiles. For most soil profiles low exchangeable sodium percentage (ESP) indicates a low sodicity hazard and the highest ESP values are associated with high salinity and dominance of soluble sodium in the soil solution. However, most of the soil profiles under study are coarse textured, which facilitate the possibility to decrease the exchangeable sodium percentage (ESP) if an efficient drainage system is established. The CEC value of these soil samples ranges from 1.38 to $45.84 \mathrm{cmol}^{(+)} / \mathrm{kg}$ with a mean value of $11.15 \mathrm{cmol}^{(+)} / \mathrm{kg}$ while the weighted mean value of CEC vary from 1.85 to $37.69 \mathrm{cmol}^{(+)} / \mathrm{kg}$ it is listed in (Table 4 and present in Fig. 8-B).
The pattern of soluble cations and anions (Fig. 9 and 10) reveres that $\mathrm{NaCl}, \mathrm{CaCl}_{2} \mathrm{NaHCO}_{3}, \mathrm{MgCl}_{2}$, $\mathrm{NaSO}_{4}$ and $\mathrm{MgSO}_{4}$ predominate the soluble salts in the area under study. The soil profiles have high concentrations of more soluble neutral salts than $\mathrm{Ca}$ and $\mathrm{Mg}$ carbonate in the eastern part of the study area. Alkaline soils which have exchangeable sodium percentage more than $15 \%$ and high $\mathrm{pH}$ values $>8.5$ indicates to highly content of sodium carbonate $\left(\mathrm{Na}_{2} \mathrm{CO}_{3}\right)$. In general, the dominance of salt composition in soils is $\mathrm{Na}$ and $\mathrm{Ca}$ carbonates and sometimes $\mathrm{Mg}$ in sodic soils. The cationic composition of the soil saturation extract of most soil layers is dominated by $\mathrm{Na}^{+}$followed by $\mathrm{Ca}^{+2}$ and then $\mathrm{Mg}^{+2}$ and $\mathrm{K}^{+}$. Exceptional cases were found in some soil samples $\mathrm{Ca}^{+2}$ exceed $\mathrm{Na}^{+}$. The anionic composition is characterized by the dominance of $\mathrm{Cl}^{-}$followed by $\mathrm{HCO}_{3}^{-}$then $\mathrm{SO}_{4}{ }^{-2}$ while $\mathrm{CO}_{3}{ }^{-2}$ in entirely absent. 

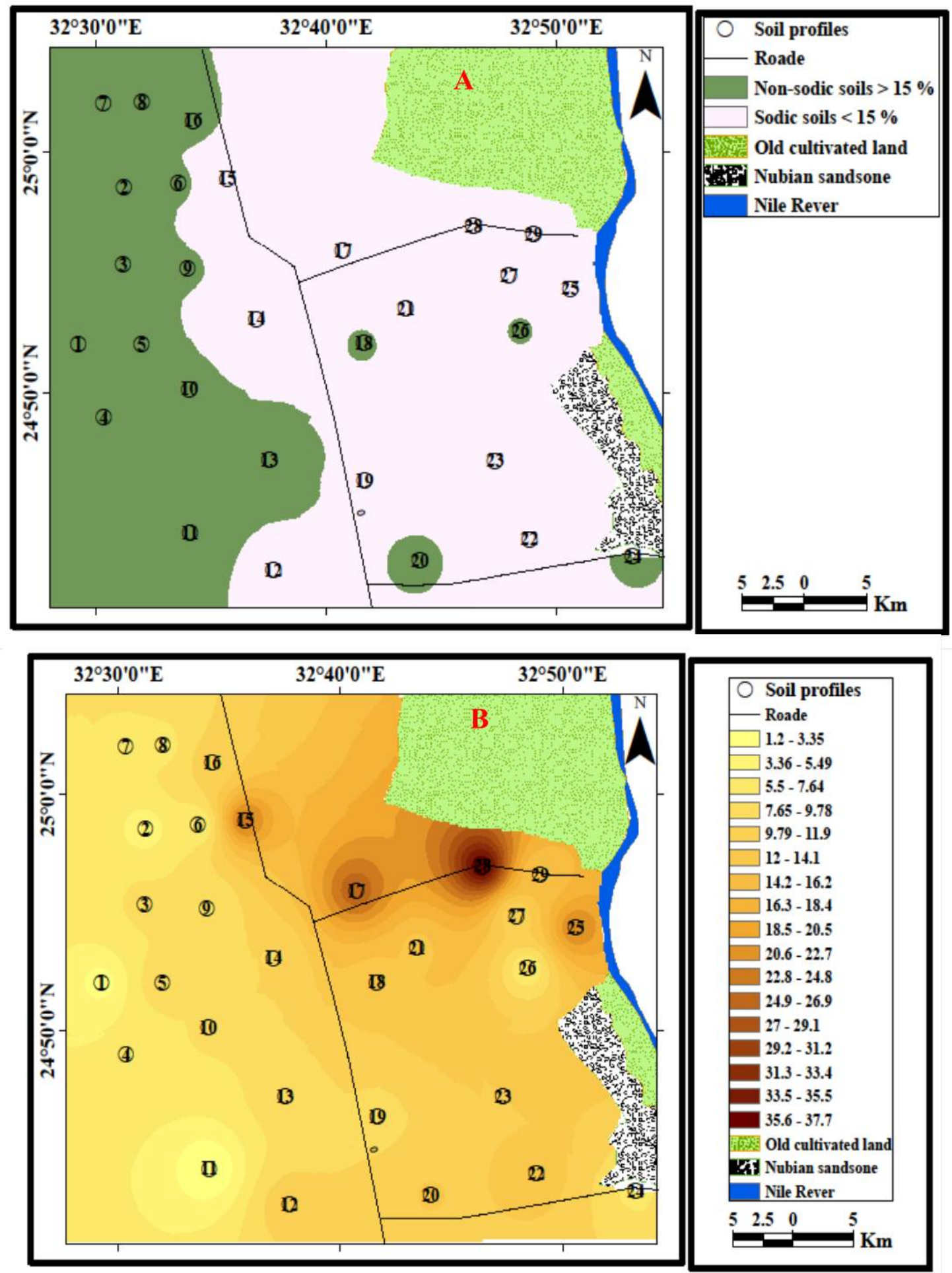

Fig.8: Spatial distribution of A) (ESP \%) and B) cation exchange capacity (CEC $\mathrm{cmol}^{(+)} / \mathrm{kg}$ ) of weighted profiles mean in the area under study 

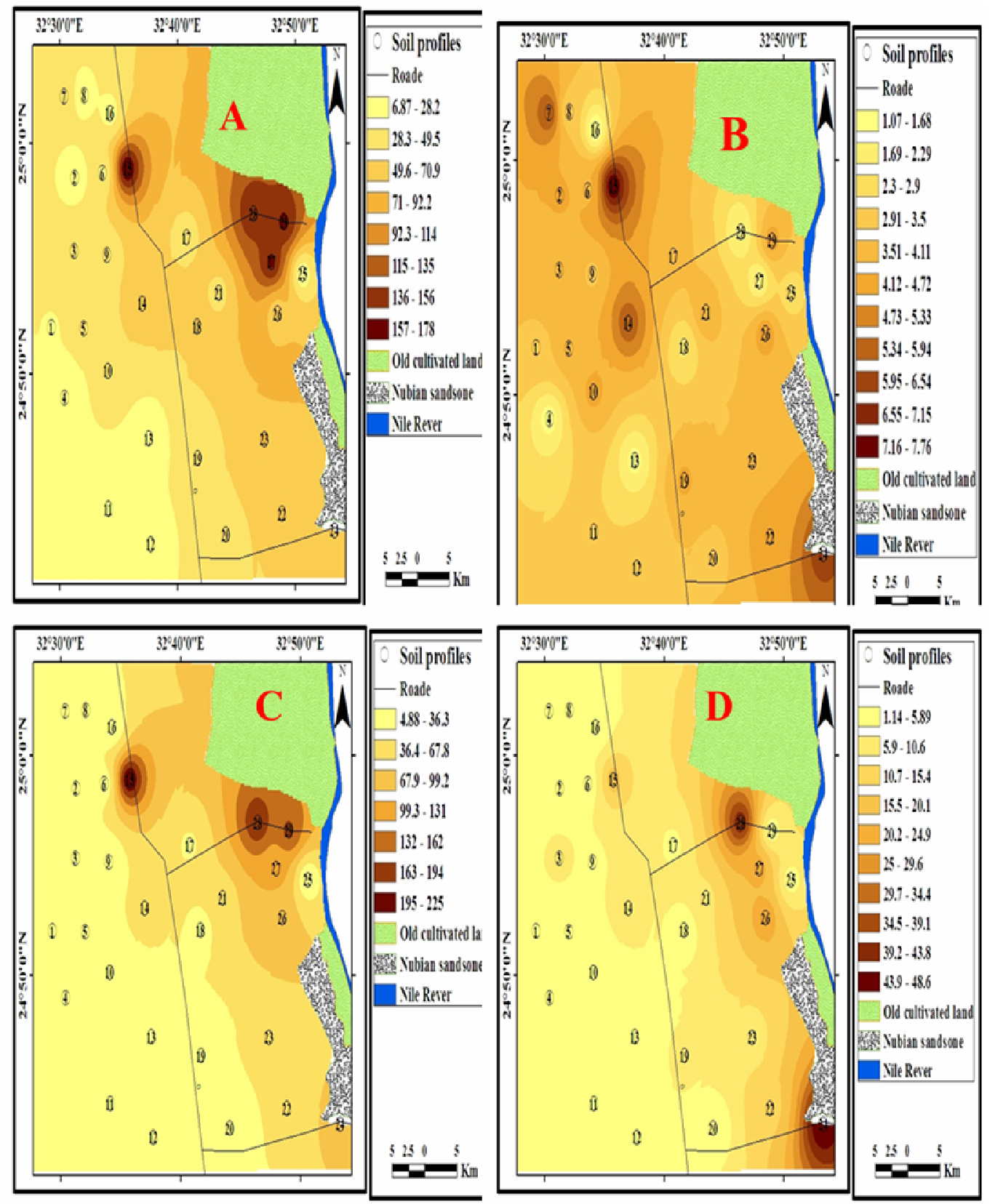

Fig.9: Spatial distribution of A) sodium, B) potassium, C) calcium and D) magnesium of weighted profiles mean in the area under study 

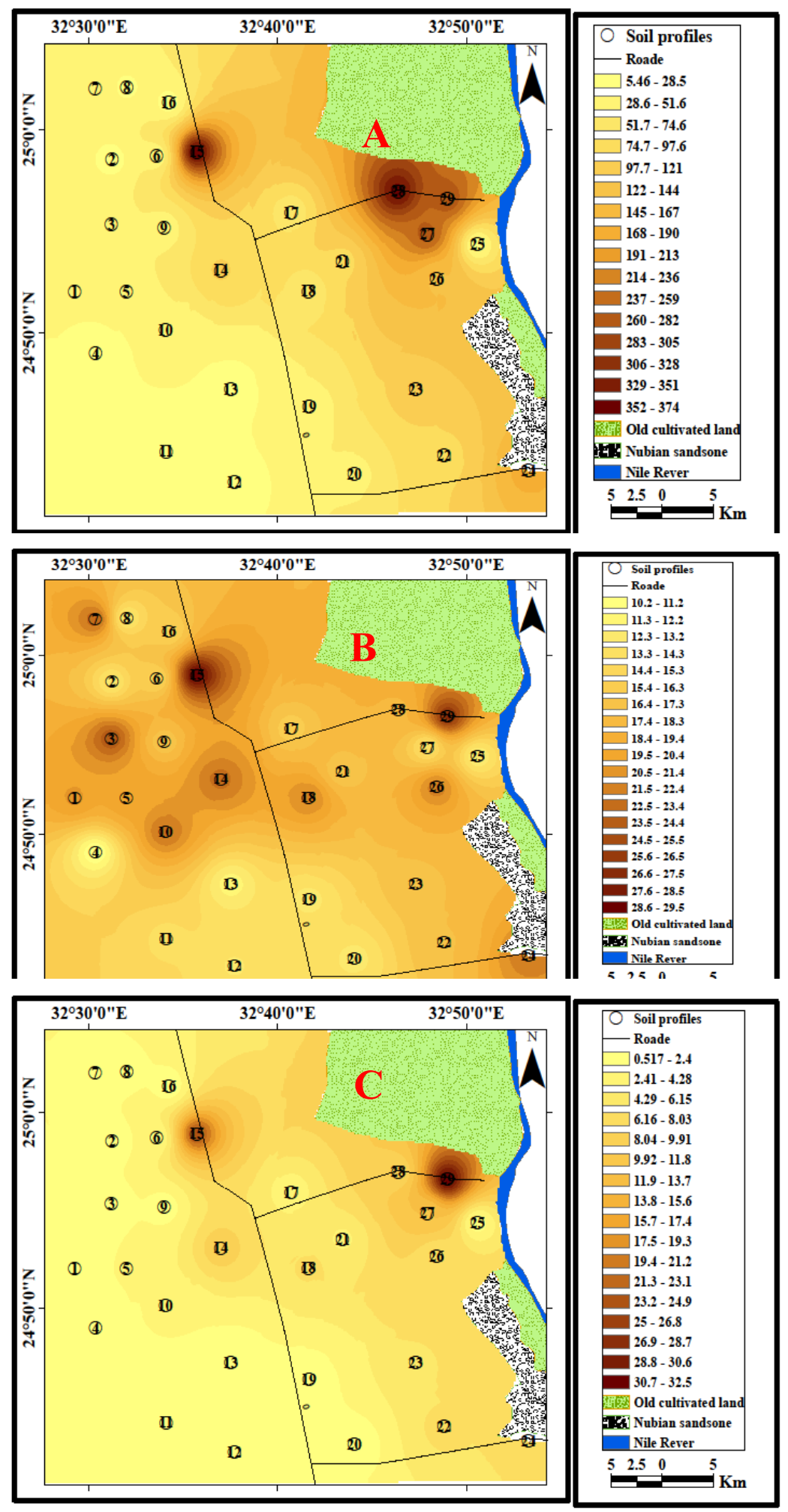

Fig.10: Spatial distribution of A) chloride, B) bicarbonate and C) sulfate of weighted profiles mean in the area under study. 


\section{Conclusion:}

It could be concluded that soils in west Edfu have great variations in their physiochemical properties between their mapping units. Most of these properties were influenced by their soil pedology. The majority of soils in the study area are sandy and the values of saturation percentages (SP) and soil porosity were low especially in the western part of the study area, whereas the higher content of bulk density values of the soil samples due to their relatively higher content of sand fraction and lowest content of silt and clay. On the other hand, most soil samples in the study area have $\mathrm{pH}$ values were moderately alkaline and the $\mathrm{EC}_{\mathrm{e}}$ values vary from salt free to moderately saline in most soil samples. In most cases, total calcium carbonate increases towards profiles deepest layers. Gypsum content values were classified into two classes including slightly gypsiric (0 $5 \%$ ) and moderately gypsiric (5 $15 \%$ ). CEC values were low in most of the studied soils and highest values of ESP are associated with subsurface and the deepest layers of profiles.

\section{References}

Blake G. R. and Hartge, K. H. (1986). Particle density. P. 377-382. In A. Klute (ed.) "Methods of Soil Analysis" part 1. Physical and Mineralogical Methods. Agron. Monogr. 9. $2^{\text {nd }}$ ed. ASA and SSSA. Madison. WI.

Bodman, A.G. (1946). Memiographed laboratory notes on soil characteristics. University of California, U.S.A.

Cooke, G.W. (1967). The Control of Soil Fertility. Crosby Lockwood \& Son Ltd, London, 526 pp.

Danielson, R.E. and Sutherland, P.L. (1986). Porosity. In: Klute, A. (ed.), Methods of Soil Analysis. Part 1: Physical properties. American Society of Agronomy, Madison, 443-460.

EI-Shazly, E.M., H.A. Abdel-Hady, M.A. El-Ghawaby and I.A. EIKasas, (1975). Geologic interpretation of ERTS-1 Satellite Images for West Aswan Area, Egypt. The Remote Sensing Research Project, Acadamy of Scientific Research and Technology, Cairo, 299-311.

El-Baz, Farouk. (2007). Development Corridor: Securing a Better Future for Egypt, El-Ain Publishing House, Egypt.

FAO (2006). Soil description, Carbonates, $38 \mathrm{iV}$. FAO Viale delle Terme di Caracalla, 00100 Rome, Italy. Guidelines for soil description, Book.

FAO. (2003). Review of world water resources by country.Water Report 23. FAO, Rome (Italy). Land and Water Development Division, 110 pp.

Farrage, A. A., (1982). Hydrogeological studies on the quaternary water bearing sediments in the area between Assiut and Aswan. M.Sc. thesis, Faculty of Science, Assiut University.

Ghafari, A., Cook, H.F., Lee, H.C., (2000). Integrating climate, soil and crop information: a land suitability study using GIS. In: $4^{\text {th }}$ International Conference on Integrating GIS and Environmental Modeling (GIS/EM4). Problems, Prospects and Research Needs, Banf, Alberta.

Issawi, B., (1981). Geology of the southwestern Desert of Egypt, Geol. Surv. Egypt. Cairo XI: 57-66.

Jackson, M.L. (1973). Soil Chemical Analysis. Prentice-Hall of India 
private limited, New Delhi, pp. 498.

Muhaimeed, A.S. and Saleh, A.M. (2013). Spatial Variability Analysis of Selected Soil Properties at Musayab, Babil, Iraq. J. of Agriculture and Veterinary Science (IOSR-JAVS), 6 (3): 72-79. Paudel and Sah, 2003.

Nelson, R.E. (1982). Carbonate and gypsum. p. 181-197. In A.L. Page (ed.) Methods of soil analysis. Part 2.2nd ed. Agron. Monogr. 9. ASA and SSSA, Madison, WI.

Nwachokor, M.A., Uzu, F.O. and Molindo W.A., (2009). Variations in Physicochemical Properties and Productivity Implications for Four Soils in the Derived Savannah of Southern Nigeria, AmericanEurasian Journal of Agronomy, 2(3), 124-129.

Olueh, C.E. (2014). Evaluation of potassium status in some soils of Delta state, Nigeria. Ph.D. Thesis Department of Soil Science, Ambrose, Alli University, Ekpoma, Edo State, Nigeria.

Paudel S, Salah J.P., (2003). Physiochemical characteristics of soil in tropical sal (Shorea robusta) forests in eastern Nepal. Himal J Sci $1: 107-110$

Papadopoulos, A., Bird, N. R. A., Whitmore, A.P. and Mooney S.J. (2006). The effect of organic farming on the soil physical environment. Aspects Appl. Biol. 79, 263267.

Piper, C. S. (1950). Soil and plant analysis, International Science Publisher, Inc., New York.
Richards, L.A. (1954). Diagnosis and Improvement of saline and alkali soils.United States Salinity Laboratory Staff, Department of Agriculture, Handbook, No. 60 California, USA.

S. Paudel, J.P. Sah (2003). Physiochemical characteristics of soil in tropical sal (Shorea robusta Gaertn.) forests in eastern Nepal Himal. J. Sci., 1, pp. 107-110.

Saleh, A.M., Belal, A.A., (2014). Delineation of site-specific management zones by fuzzy clustering of soil and topographic attributes: a case study of East Nile Delta, Egypt. In: $8^{\text {th }}$ International Symposium of the Digital Earth (ISDE8). IOP Conf. Series: Earth and Environmental Science 18 (2014) 012046. IOP Publishing.

Saleh, A.M., Belal, A.A., Arafat, S.M., (2013). Identification and mapping of some soil types using field spectrometry and spectral mixture analyses: a case study of North Sinai, Egypt. Arabian J. Geosci. 6 (6), 1799-1806.

Soil Survey Staff. (1951). Soil survey manual. U.S. Dep. Agri. Handbook, No. 18, U.S. Government printing office, Washington, D.C. PP. 503.

Soil Survey Staff. (2014). Keys to Soil Taxonomy, $12^{\text {th }}$ ed. USDA-Natural Resources Conservation Service, Washington, DC.

Sys, C. and W. Verheye. (1978). An attempt to the evaluation of physical land characteristics for irrigation according to the FAO framework for land evaluation. Chent: 78707258- 78707258 . 
تقييم بعض الخواص الفيزيائية والكيميائية للتربة بمنطقة غرب إدفو، محافظة أسوان، مصر

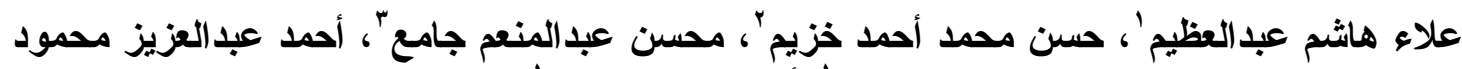

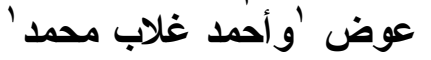

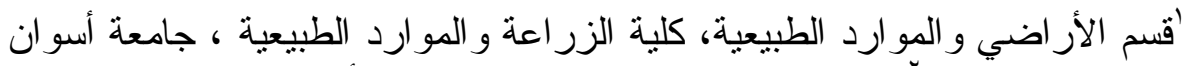

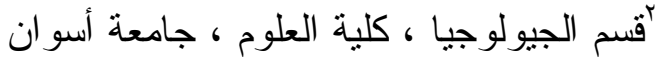

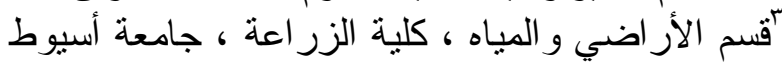

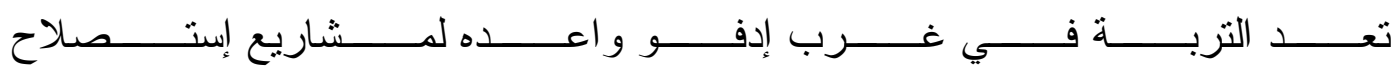

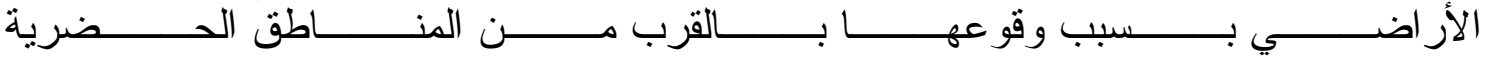

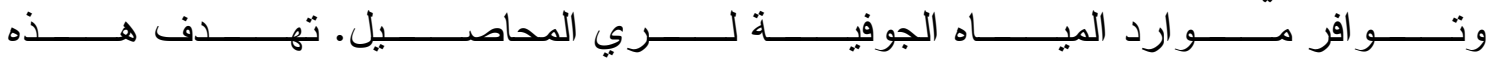

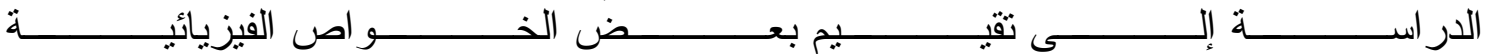

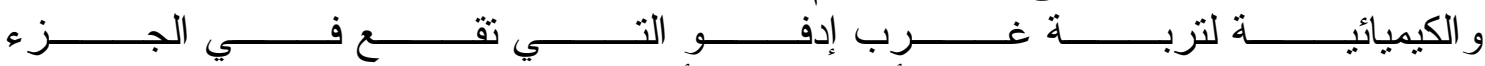

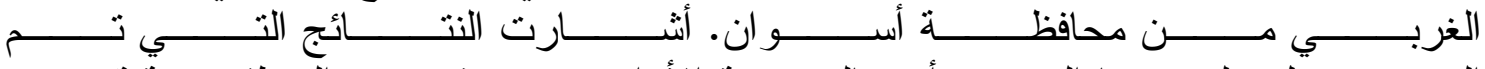

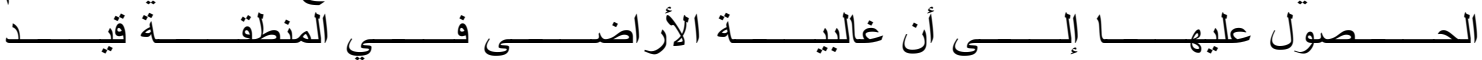

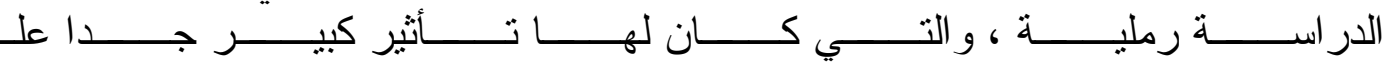

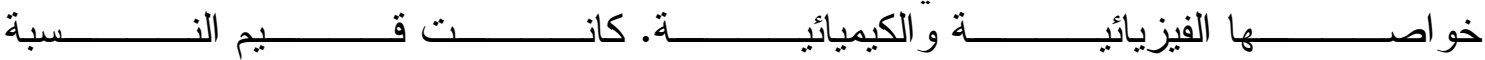

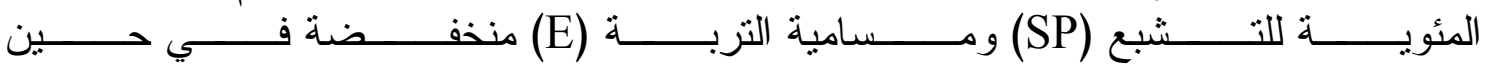

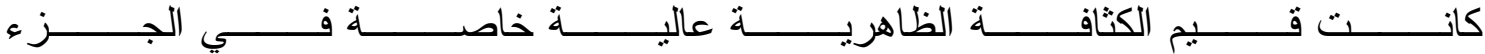

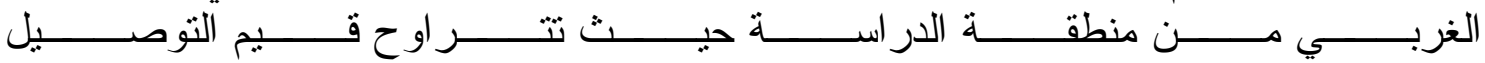

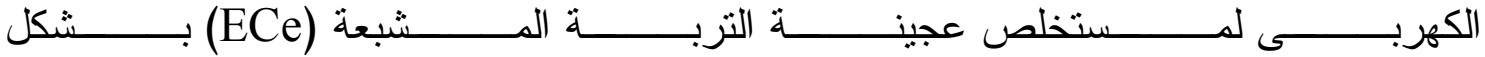

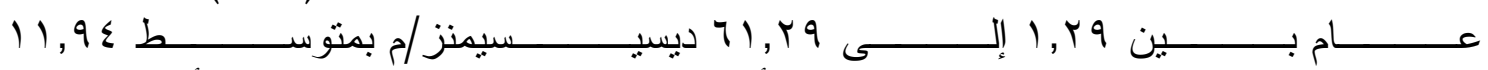

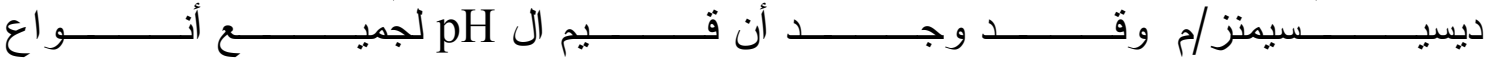

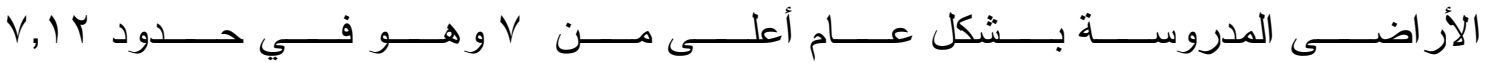

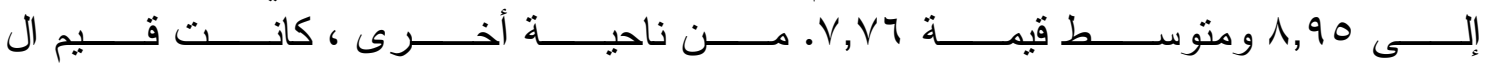

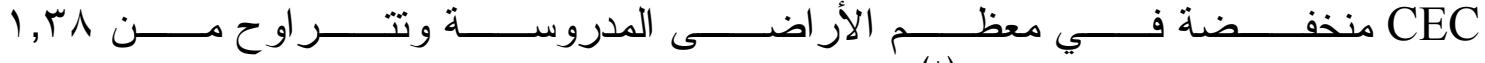

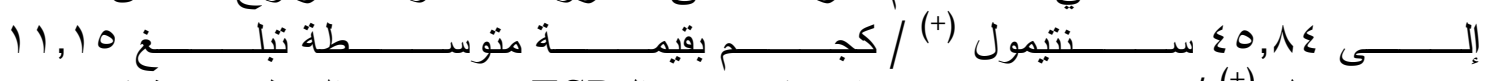

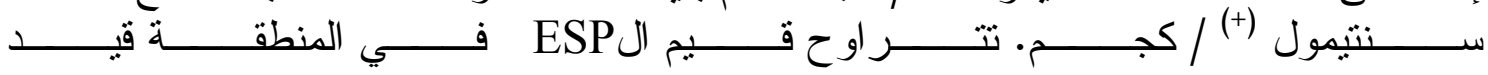

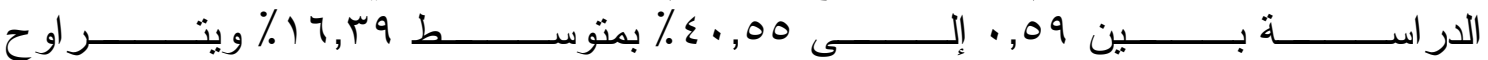

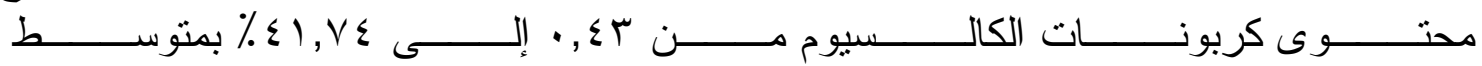

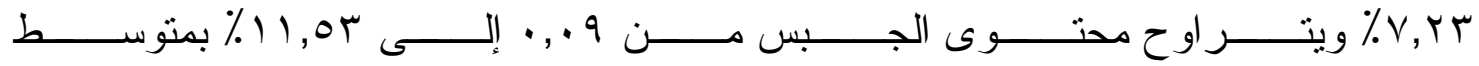

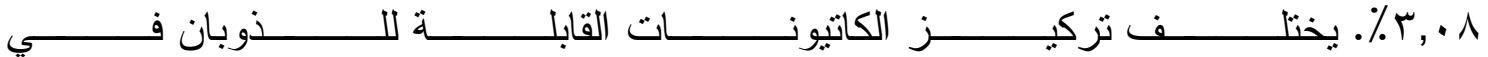

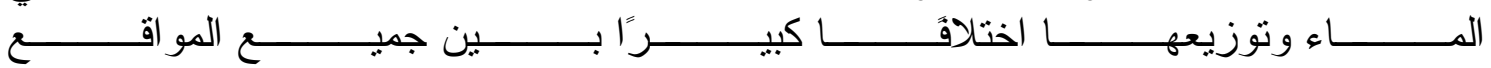

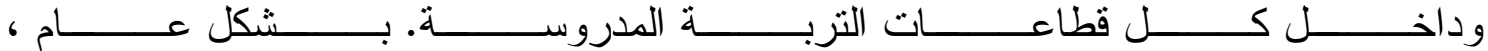

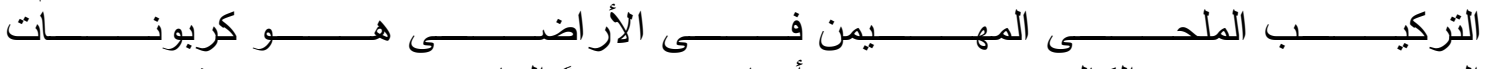

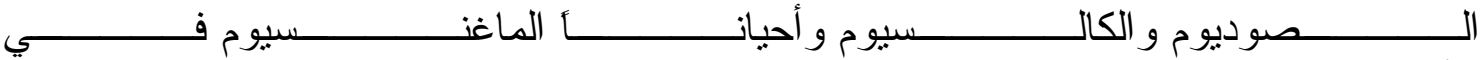

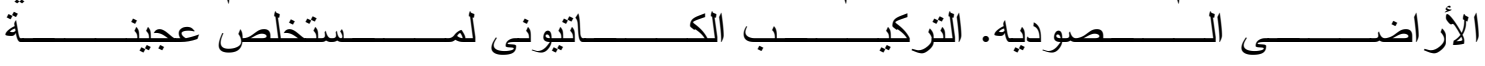

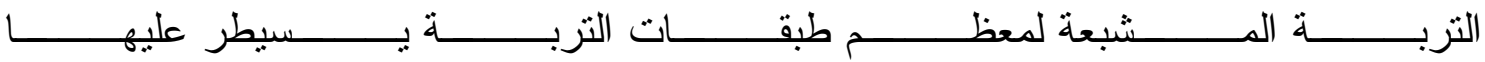

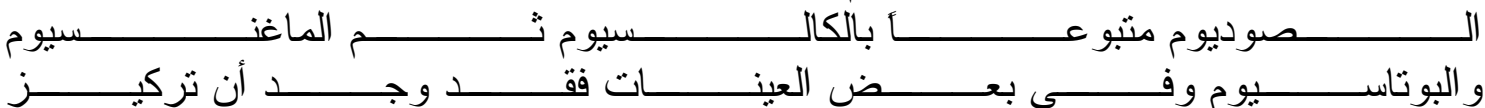

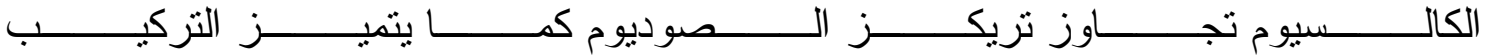

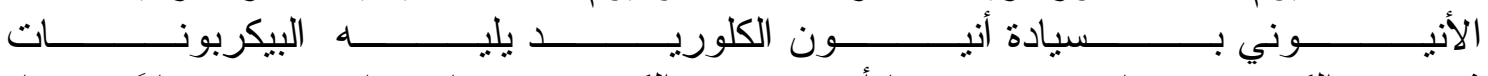

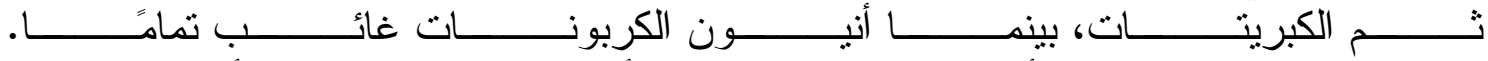

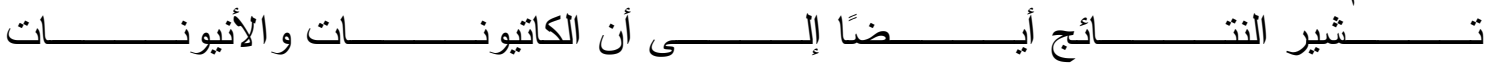

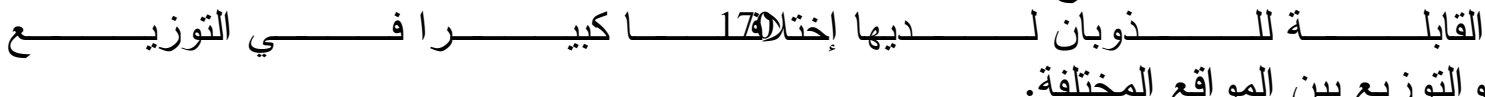

